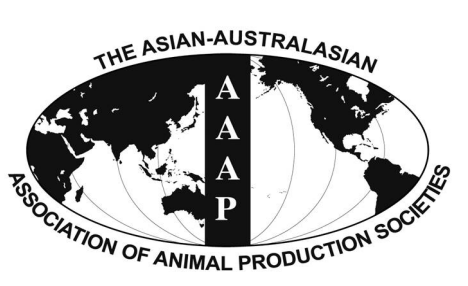

\begin{tabular}{c} 
Open Access \\
Asian Australas. J. Anim. Sci. \\
Vol. 29, No. 4 : 599-605 April 2016 \\
http://dx.doi.org/10.5713/ajas.15.0863 \\
\hline www.ajas.info \\
pISSN 101 1-2367 elSSN 1976-5517
\end{tabular}

\title{
Characteristics of Rice Hulls, Sawdust, Wood Shavings and Mixture of Sawdust and Wood Shavings, and Their Usefulness According to the Pen Location for Hanwoo Cattle
}

\author{
Gyu Chul Ahn", Sun Sik Jang ${ }^{1, a}$, Hyung Jun Kwak, Sang Rak Lee, \\ Young Kyun $\mathrm{Oh}^{1}$, and Keun Kyu Park* \\ Department of Animal Science and Technology, College of Animal Bioscience and Technology, \\ Konkuk University, Seoul 143-701, Korea
}

\begin{abstract}
In this study, two experiments were conducted to investigate the physicochemical characteristics (Exp. I) of bedding materials such as rice hulls (RH), sawdust (SD), wood shavings (WS) and sawdust+wood shavings (S+W; 1:1 in volume), and utilization of these beddings except RH (Exp. II) for rearing beef cattle. In Exp. I, the distribution of particle size (\%) with $250 \mu \mathrm{m}$ and below $250 \mu \mathrm{m}$ was greater $(\mathrm{p}<0.05)$ in SD (30.4) than RH (4.4), WS (18.8) and $\mathrm{S}+\mathrm{W}(20.1)$. Bulk density $\left(\mathrm{kg} / \mathrm{m}^{3}\right)$ of bedding materials was directly proportional to the percentage of $250 \mu \mathrm{m}$ and below $250 \mu \mathrm{m}$ particles, $178,46,112$, and 88 for SD, WD, S+W and RH, respectively. Water absorption rate $(\%)$ after submersion in water for $24 \mathrm{~h}$ was higher $(\mathrm{p}<0.05)$ in WS (540.2) compared to SD (270.2), $\mathrm{S}+\mathrm{W}$ (368.2). The $\mathrm{S}+\mathrm{W}$ had an intermediate value of the absorption rate between SD and WS, but had an outstanding durability of water absorption capacity. Moisture evaporation rate $(\%)$ for $12 \mathrm{~h}$ was higher $(\mathrm{p}<0.05)$ in WS (75.4) than SD (70.5), S+W (72.2) and RH (57.8). Average ammonia emission $\left(\mathrm{mg} / \mathrm{m}^{2} / \mathrm{h}\right)$ for $36 \mathrm{~h}$ was higher $(\mathrm{p}<0.05)$ in $\mathrm{RH}(3.15)$ than SD (1.70), WS (1.63), and S+W (1.73). In Exp. II, thirty six Hanwoo cows were allocated in 9 pens with one side on feed bunk side (Side A) and another side equipped with water supply (Side B) for 3 weeks with duplicated periods. Average moisture concentrations (\%) of beddings were higher ( $\mathrm{p}<0.05)$ in WS (side A, 65.7; side B, 57.9) than SD (side A, 62.5; side B, 52.2) and S+W (side A, 61.6; side B, 50.7). Regardless of types of beddings, moisture concentrations $(\%)$ of beddings within a pen were lower $(\mathrm{p}<0.05)$ at side $\mathrm{B}$ than $\mathrm{A}$, implying longer period of utilization. These results suggest that using $\mathrm{S}+\mathrm{W}$ would be a better choice than $\mathrm{SD}$ or WS alone, considering physicochemical characteristics and economics, and RH is not a suitable material as a bedding for beef cattle. (Key Words: Animal Welfare, Bedding, Sawdust, Wood Shavings, Rrice Hulls, Ammonia Emission)
\end{abstract}

\section{INTRODUCTION}

In South Korea, there is increasing public concern about the welfare of farm animals, but relatively little information has been published regarding the effect on farm animal welfare of managing farm environment, especially bedding materials for rearing beef cattle. In Korean farm

\footnotetext{
* Corresponding Author: Keun Kyu Park. Tel: +82-2-450-3661,

Fax: +82-2-455-1044, E-mail: kkpark@konkuk.ac.kr

${ }^{1}$ National Institute of Animal Science, RDA, Jeonju 331-808, Korea.

${ }^{\mathrm{a}}$ These two authors contributed equally to this work.

Submitted Oct. 20, 2015; Revised Dec. 11, 2015; Accepted Jan. 7, 2016
}

environment, Hanwoo spend most of their time on beddings, thus proper bedding management is important to maximize productivity and welfare of farm livestock.

Floor type and bedding materials on the floor may have no significant effect on performance, carcass characteristics and meat quality of beef cattle (Lowe et al., 2001). According to Olson (1940) and Lowe et al. (2001), however, floor type and bedding materials in the pen affect welfare of farm animal, and management of bedding materials can affect production cost of rearing beef steers. Using a proper bedding material is important, therefore, the farmer should know which materials meet these requirements at the lowest cost and suitable for animal welfare. From the farm animal 
welfare point of view, a proper bedding management can be associated with at least three out of five freedoms by RSPCA (2015), freedom from discomfort, freedom from pain, injury or disease and freedom from fear and distress.

Sawdust (SD), wood shavings (WS), and rice hulls (RH) are the most common bedding materials in South Korea. Sawdust and WS are by-products from woodworking companies during the wood processing. Pine trees are the most common material that used for wood processing, and pine trees are usually imported from Russia (Pinus sylvestris) and New Zealand (Pinus radiata). Rice hulls are from South Korea, but not used broadly for bedding materials by farmers because of low water absorption capacity. However, there are little scientific evidence available concerning the physicochemical characteristics of RH, $\mathrm{SD}$, and WS as bedding materials. The objectives of this study were to investigate the characteristics of RH, SD, and WS and the mixture of SD and WS (1:1 in volume), then to evaluate the suitability of each bedding material for rearing Hanwoo cattle and to study location effects within a pen (feed bunk side vs water supply side) on moisture concentration and increment.

\section{MATERIALS AND METHODS}

\section{Exp. I. The physicochemical property of bedding materials}

The physicochemical properties (particle size distribution, bulk density, moisture concentration, water absorption rate, moisture evaporation rate and in vitro ammonia emission) of bedding materials were evaluated by the method reported by Ahn et al. (2015).

Preparation of bedding materials: In Exp. I, SD, WS, the mixture of SD and WS (S+W; 1:1 in volume), and $\mathrm{RH}$, were used to evaluate physicochemical properties of types of bedding materials. Raw materials of SD and WS were a mixture of pine trees originating from Russia (Pinus sylvestris) and New Zealand (Pinus radiata). The mixing ratio of two types of pine trees depends on the availability and usage of these trees in a wood processing company. Both SD and WS were obtained from a commercial woodprocessing company in Namdong industrial complex, Incheon, South Korea and transported to the experimental farm located at Yongin, Gyeonggi-Do, South Korea. The $\mathrm{RH}$, which are husks of rice occurred from rice processing, were obtained from commercial rice milling plant located in Gyeonggi-do Province, South Korea.

Particle size distribution and bulk density: Particle size distributions of SD, WS, S+W, and RH were measured by five dry sieves (Testing sieve, Chunggyesanggongsa, Seoul, South Korea) with mesh screen size of 11.2, 3.35, 2.00, and $1.00 \mathrm{~mm}$ and $250 \mu \mathrm{m}$, respectively. A sample of unused bedding material $(100 \mathrm{~g})$ was passed through mesh screens and retained bedding materials were weighed. The test was replicated six times and the percentage of particle size distribution was calculated from the weight value.

The bulk density was determined by calculating kilograms of each bedding material in a $100 \times 100 \times 5 \mathrm{~cm}$ (width $\times$ length $\times$ height) wooden box and multiplied by 20 times for calculating the weight of $1 \mathrm{~m}^{3}$ of each bedding material. To evaluate the moisture concentration of bedding materials, a forced-air dry oven (SJ201D, Sejong Scientific Co., Seoul, South Korea) was used at $105^{\circ} \mathrm{C}$ for overnight (over 12 hours).

Water absorption rate: The water absorption rate of bedding materials was measured in a Berzelius beaker (500 $\mathrm{mL}$ ) using a filter paper (No. 417, VWR, PA, USA). Bedding samples were prepared for SD (30 g), WS (15 g), $\mathrm{S}+\mathrm{W}(25 \mathrm{~g})$, and RH (20 g) and filled with distilled water (DW), and filtrated at each sampling time. The water absorption rate was measured at $1,2,3,4,8,12$, and $24 \mathrm{~h}$ after submersion.

Moisture evaporation rate: For measuring moisture evaporation rates, triplicated $140 \mathrm{~g}$ of each unused dry bedding material was prepared. Prior to the measuring test, bedding samples were fully submerged in DW for $24 \mathrm{~h}$. A fan (SIF-20FOG, Shinil, Seoul, South Korea) was used to evaporate moisture by blowing air at $2 \mathrm{~m} / \mathrm{s}$, similar to that in a common cattle-rearing farm in South Korea, and bedding samples were weighted and the moisture evaporation rate calculated hourly from 1 to $12 \mathrm{~h}$.

In vitro ammonia emission: Total and hourly in vitro ammonia emissions were measured by the laboratory chamber system described by Ahn et al. (2015). Four airtight glass chambers (width, $26 \mathrm{~cm} \times$ length, $20 \mathrm{~cm} \times$ height, $13 \mathrm{~cm}=$ volume, $6.76 \mathrm{~L}$ ) for each sample were prepared and connected to an acid trap $(100 \mathrm{~mL}$ of $0.9 \mathrm{M}$ sulfuric acid; Burkholder et al., 2004) to collect ammonia emission from the mixture of bedding materials ( $400 \mathrm{~g})$, feces $(200 \mathrm{~g}$ ) and water (to adjust to $60 \%$ of moisture concentrations). After mixing of bedding materials, feces and water, the height of the mixture in a measuring chamber was similar (approximately $5 \mathrm{~cm}$ ) to that of bedding material at farms in South Korea. A gas pump (13 watts, YP-15A, Yonugnam Air Pump Inc., Busan, South Korea) was used to send ammonia emission gases from the beddings in the chamber to acid trap. Total and hourly ammonia emission rates were calculated in $1,3,6,12,24$, and $36 \mathrm{~h}$ after operating gas pump by replacing fresh acid traps in every sampling time.

Statistical analysis: Data obtained from the evaluation of physicochemical properties of each bedding material were subjected to statistical analysis using the general linear model (GLM) procedure of SAS (SAS Institute, 2002; version 9.03). Data were analyzed by variance analysis and Duncan's multiple range tests were used to determine significant differences $(\mathrm{p}<0.01$ and 0.05$)$ among bedding 
materials within each treatment.

Exp. II. The evaluation of bedding materials by types and the species of pine trees for Hanwoo cattle

Preparation of bedding materials: For Exp. II, the same bedding materials as used in Exp. I were prepared except RH. The RH treatment was excluded in Exp. II, because of relatively low quality of physicochemical characteristics.

Experimental design: For Exp. II, SD, WS, and S+W originating from Russia and New Zealand were prepared. Thirty six Hanwoo cows were allocated to each of three types of bedding materials, and an experimental period was 21 days and performed duplicated (6 weeks; October to November). Triplicated pens were allocated to one of three bedding materials, thus total 9 pens were used in this study. The cows were housed in pens ( 4 cows $/$ pen; $4.0 \mathrm{~m}$ wide $\times$ $8.2 \mathrm{~m}$ length $=32.8 \mathrm{~m}^{2} /$ pen; $8.2 \mathrm{~m}^{2}$ for each cow) with one side a $4.0 \mathrm{~m}$ wide feed bunk side (side A) and another side equipped with water supply (side B). There was a shallow divider (15 cm height $\times 20 \mathrm{~cm}$ wide) made of concrete between $\mathrm{A}$ and $\mathrm{B}$.

Offered feeds in this study were total mixed ration and the chemical composition of the diet is described in Table 1. Cows were offered feeds $5 \mathrm{~kg}$ equally at 06:00 and 17:00 h on daily basis (10 kg/d for each cow, as fed basis), and allowed to access fresh water and mineral block without any restriction during the whole experimental period. Blowing fans (diameter $=1,025 \mathrm{~mm}, 790 \mathrm{rpm}$; DVN-1007, Dongkun Industrial Co., Ltd, Incheon, South Korea) were installed and operated at $2 \mathrm{~m} / \mathrm{s}$ (measured by digital anemometer; AR-836, Smart Sensor, Guangdong, China) in every two pen for maximizing the usability of bedding materials.

Sampling and analysis of beddings: In Exp. II, beddings samples were collected every week at 10:00 AM from 12 sampling spots per pen by grab sampling to avoid sampling

Table 1. Chemical composition of experimental diet

\begin{tabular}{|c|c|}
\hline Items & Concentration (\%) \\
\hline \multirow[t]{2}{*}{$\overline{\mathrm{DM}}$} & 59.90 \\
\hline & ---- \% of DM -- \\
\hline $\mathrm{CP}$ & 15.28 \\
\hline $\mathrm{EE}$ & 3.34 \\
\hline $\mathrm{CF}$ & 17.89 \\
\hline Ash & 8.60 \\
\hline NDF & 39.76 \\
\hline $\mathrm{ADF}$ & 20.50 \\
\hline Lignin & 2.86 \\
\hline $\mathrm{Ca}$ & 0.84 \\
\hline $\mathrm{P}$ & 0.44 \\
\hline
\end{tabular}

DM, dry matter; $\mathrm{CP}$, crude protein; EE, ether extract; $\mathrm{CF}$, crude fiber; NDF, neutral detergent fiber; $\mathrm{ADF}$, acid detergent fiber; $\mathrm{Ca}$, calcium; P, phosphorus. bias. Obtained bedding samples were transported immediately to the laboratory for measuring moisture concentrations by a forced-air dry oven (SJ201D, Sejong Scientific Co., Seoul, South Korea; $105^{\circ} \mathrm{C}$; overnight, more than $12 \mathrm{~h}$ ). Ammonia concentrations and $\mathrm{pH}$ in these samples were not measured because these beddings were not good indicators of changes in the ammonia situation at farms (Ahn et al., 2015).

Statistical analysis: Data obtained from the evaluation of bedding materials for Hanwoo cattle were subjected to statistical analysis using the GLM procedure of SAS (SAS Institute, 2002; version 9.03). Data were analyzed by variance analysis and Duncan's multiple range tests were used to determine significant differences $(p<0.01$ and 0.05$)$ among bedding materials within each treatment.

\section{RESULTS AND DISCUSSION}

Exp. I. The physicochemical properties of bedding materials by types and the species of pine trees

Particle size distribution, bulk density and moisture concentration of bedding materials: The particle size distribution, bulk density and moisture concentration of bedding materials are shown in Table 2. The WS showed the largest distribution on sieve size with $3.35 \mathrm{~mm}(41.3 \%)$ among sieve sizes and higher proportion of these particles than other treatments $(p<0.05)$, retaining relatively bigger particles than other bedding materials.

$\mathrm{RH}$ showed the largest percentage $(76.3 \%)$ of particles with $2.00 \mathrm{~mm}$ sieve size among the whole treatment $(p<0.05)$ and the whole sieve size, showing the most uniform particle size. The SD and $\mathrm{S}+\mathrm{W}$ showed the largest distribution of particles with $1.00 \mathrm{~mm}(50.6 \%$ and $47.7 \%$ for $\mathrm{SD}$ and $\mathrm{S}+\mathrm{W}$, respectively). The SD showed the largest particles on sieve size with $250 \mu \mathrm{m}+<250 \mu \mathrm{m}(30.4 \%)$ among treatments $(\mathrm{p}<0.05)$, having relatively smaller

Table 2. Particle size distribution, bulk density and moisture concentrations of bedding materials

\begin{tabular}{lccccc}
\hline \multirow{2}{*}{ Particle size } & \multicolumn{5}{c}{ Particle size distribution (\%) } \\
\cline { 2 - 5 } & SD & WS & S+W & RH & \\
\hline $11.2 \mathrm{~mm}$ & $0.00^{\mathrm{b}}$ & $2.80^{\mathrm{a}}$ & $0.13^{\mathrm{b}}$ & $0.00^{\mathrm{b}}$ & 0.11 \\
$3.35 \mathrm{~mm}$ & $5.13^{\mathrm{c}}$ & $41.30^{\mathrm{a}}$ & $16.00^{\mathrm{b}}$ & $3.57^{\mathrm{c}}$ & 1.80 \\
$2.00 \mathrm{~mm}$ & $10.90^{\mathrm{c}}$ & $12.37^{\mathrm{bc}}$ & $13.57^{\mathrm{b}}$ & $76.27^{\mathrm{a}}$ & 0.55 \\
$1.00 \mathrm{~mm}$ & $50.63^{\mathrm{a}}$ & $19.50^{\mathrm{c}}$ & $47.73^{\mathrm{b}}$ & $17.67^{\mathrm{c}}$ & 0.95 \\
$250 \mu \mathrm{m}$ & $30.27^{\mathrm{a}}$ & $17.07^{\mathrm{b}}$ & $19.87^{\mathrm{b}}$ & $3.90^{\mathrm{c}}$ & 1.18 \\
$<250 \mu \mathrm{m}$ & $0.10^{\mathrm{c}}$ & $1.76^{\mathrm{a}}$ & $0.23^{\mathrm{bc}}$ & $0.45^{\mathrm{b}}$ & 0.11 \\
$250 \mu \mathrm{m}+<250 \mu \mathrm{m}$ & $30.37^{\mathrm{a}}$ & $18.83^{\mathrm{b}}$ & $20.10^{\mathrm{b}}$ & $4.35^{\mathrm{c}}$ & 1.19 \\
Bulk density $\left(\mathrm{kg} / \mathrm{m}^{3}\right)$ & $178^{\mathrm{a}}$ & $46^{\mathrm{d}}$ & $112^{\mathrm{b}}$ & $88^{\mathrm{c}}$ & 2.24 \\
Moisture $(\%)$ & $16.4^{\mathrm{a}}$ & $11.7^{\mathrm{c}}$ & $14.8^{\mathrm{b}}$ & $8.7^{\mathrm{d}}$ & 0.31 \\
\hline
\end{tabular}

SD, sawdust; WS, wood shavings; S+W, mixture of sawdust and wood shavings (1:1 in volume); RH, rice hulls; SEM, standard error of means.

${ }^{\mathrm{a}-\mathrm{d}}$ Means within in a row without a common superscript letter differ $(\mathrm{p}<0.05)$. 
particles than other bedding materials. On the contrary, RH showed the smallest particles on sieve size with 250 $\mu \mathrm{m}+<250 \mu \mathrm{m}(4.4 \%)$ among treatments. Ahn et al. (2015) reported that there was a dust generation problem with an increase of particle size with $250 \mu \mathrm{m}+<250 \mu \mathrm{m}$ for cocopeat beddings in an on-farm trial. In $\mathrm{S}+\mathrm{W}$, particle size values retained on each sieve were not exactly half of SD and WD, because $\mathrm{S}+\mathrm{W}$ was not mixed by the weight but by the volume (1:1) of bedding materials. It may be practical for mixing of different types of bedding materials by volume, because weighing of bedding material may be impossible prior to use in a farm.

Bulk densities of bedding materials were the highest in SD $\left(178 \mathrm{~kg} / \mathrm{m}^{3}, \mathrm{p}<0.05\right)$, followed by $\mathrm{S}+\mathrm{W}\left(112 \mathrm{~kg} / \mathrm{m}^{3}\right)>$ $\mathrm{RH}\left(88 \mathrm{~kg} / \mathrm{m}^{3}\right)>\mathrm{WS}\left(46 \mathrm{~kg} / \mathrm{m}^{3}\right)$. The highest bulk density of SD was a result from the highest proportion of particles with $250 \mu \mathrm{m}+<250 \mu \mathrm{m}$. On the contrary, bulk density of WS was 1.9 and 3.9 times lower than those of RH and SD, respectively. Low bulk density could lead to more space for storage and high transport cost in terms of amount per volume per cargo $\left(\mathrm{kg} / \mathrm{m}^{3} / \mathrm{cargo}\right)$. Because $\mathrm{S}+\mathrm{W}$ was mixed on volume basis of SD and WS, bulk density of S+W was exactly half of SD and WS, filling up the space of WS by the fine particles from SD. Initial moisture concentrations of bedding materials was the highest in $\operatorname{SD}(16.4 \%, \mathrm{p}<0.05)$ among treatments, followed by $\mathrm{S}+\mathrm{W} \quad(14.8 \%)>\mathrm{WS}$ $(11.7 \%)>\mathrm{RH}(8.7 \%)(\mathrm{p}<0.05)$.

Water absorption rate: The water absorption rate by the types of bedding materials is presented in Table 3. After soaking bedding materials in water for $1 \mathrm{~h}$, WS showed the highest water absorption rate $(519.8 \%)$ among treatments $(\mathrm{p}<0.05)$ with no statistical difference between SD and S+W. Considering of high absorption rate of water at $1 \mathrm{~h}$ and relatively low differences between 1 and $24 \mathrm{~h}$, regardless of bedding materials, most of water absorption took place within $1 \mathrm{~h}$.

From $2 \mathrm{~h}$ to the end of experiment ( $24 \mathrm{~h}$ ), the difference of water absorption capacity among bedding materials became more clear and the water absorption rate was in the

Table 3. The water absorption rate of bedding materials

\begin{tabular}{lccccc}
\hline \multirow{2}{*}{ Time (h) } & \multicolumn{4}{c}{ Water absorption rate (\%) } & \multirow{2}{*}{ SEM } \\
\cline { 2 - 5 } & SD & WS & S+W & RH & \\
\hline 1 & $225.9^{\mathrm{b}}$ & $519.8^{\mathrm{a}}$ & $254.5^{\mathrm{b}}$ & $159.6^{\mathrm{c}}$ & 5.08 \\
2 & $239.1^{\mathrm{c}}$ & $466.7^{\mathrm{a}}$ & $314.9^{\mathrm{b}}$ & $139.6^{\mathrm{d}}$ & 5.31 \\
3 & $230.2^{\mathrm{c}}$ & $563.3^{\mathrm{a}}$ & $374.4^{\mathrm{b}}$ & $150.5^{\mathrm{d}}$ & 6.35 \\
4 & $247.5^{\mathrm{c}}$ & $561.2^{\mathrm{a}}$ & $314.2^{\mathrm{b}}$ & $150.9^{\mathrm{d}}$ & 4.12 \\
8 & $266.7^{\mathrm{c}}$ & $568.7^{\mathrm{a}}$ & $342.4^{\mathrm{b}}$ & $179.6^{\mathrm{d}}$ & 5.89 \\
12 & $253.9^{\mathrm{c}}$ & $549.3^{\mathrm{a}}$ & $353.4^{\mathrm{b}}$ & $167.4^{\mathrm{d}}$ & 5.67 \\
24 & $270.2^{\mathrm{c}}$ & $540.2^{\mathrm{a}}$ & $368.2^{\mathrm{b}}$ & $179.4^{\mathrm{d}}$ & 2.37 \\
\hline
\end{tabular}

SD, sawdust; WS, wood shavings; S+W, mixture of sawdust and wood shavings (1:1 in volume); RH, rice hulls; SEM, standard error of means.

${ }^{a-d}$ Means within in a row without a common superscript letter differ $(\mathrm{p}<0.05)$. order of $\mathrm{WS}>\mathrm{S}+\mathrm{W}>\mathrm{SD}>\mathrm{RH} \quad(\mathrm{p}<0.05)$. However, the differences between 1 and $24 \mathrm{~h}$ of WS were relatively lower (20.4\% unit) than SD (44.3\% unit) and S+W (113.7\% unit). Inevitably, $\mathrm{S}+\mathrm{W}$ had an intermediate value of difference in the absorption rate between SD and WS, but had an outstanding durability of water absorption capacity. The RH treatment showed the lowest water absorption rate among treatments during all the experimental hours, and the smallest differences were also observed between 1 to $24 \mathrm{~h}$ (19.8\% unit). Therefore, RH may not be suitable as a bedding material.

There are limited data available about the water absorption rate of bedding materials. According to Ahn et al. (2015), water absorption rate of SD after $24 \mathrm{~h}$ of soaking in water was $444 \%$ and Olson (1940) reported $435 \%$ for SD, those were 1.6 times higher than this study. This discrepancy is probably caused by the differences of the species of raw material of SD and the extent of wood processing.

Moisture evaporation rate: The moisture evaporation rate by the types of bedding materials is shown in Table 4 . At $1 \mathrm{~h}$ after blowing air at $2 \mathrm{~m} / \mathrm{s}$ from water saturation, WS $(13.8 \%)$ and RH (14.4\%) showed higher moisture evaporation rates than $\mathrm{SD}(11.6 \%)$ and $\mathrm{S}+\mathrm{W}(12.2 \%)$ $(\mathrm{p}<0.05)$, but WS was not statistically different from $\mathrm{S}+\mathrm{W}$. However, RH had the lowest moisture evaporation rate from 4 to $12 \mathrm{~h}$, except at $11 \mathrm{~h}(\mathrm{p}<0.05)$, and the final percentage of moisture evaporation at $12 \mathrm{~h}$ was much lower than those of other bedding materials.

During the whole experimental hours ( 1 to $12 \mathrm{~h}$ ), WS showed the highest moisture evaporation $(p<0.05)$ among treatments, except at 9 and $10 \mathrm{~h}$. The SD treatment mostly showed lower moisture evaporation rates than WS during 1

Table 4. The moisture evaporation rate of bedding materials from water-saturation by blowing air at $2 \mathrm{~m} / \mathrm{s}$

\begin{tabular}{|c|c|c|c|c|c|}
\hline \multirow{2}{*}{ Time (h) } & \multicolumn{4}{|c|}{ Moisture evaporation rate (\%) } & \multirow{2}{*}{ SEM } \\
\hline & SD & WS & $\mathrm{S}+\mathrm{W}$ & RH & \\
\hline 1 & $11.6^{\mathrm{c}}$ & $13.8^{\mathrm{ab}}$ & $12.2^{\mathrm{bc}}$ & $14.3^{\mathrm{a}}$ & 0.30 \\
\hline 2 & $16.1^{\mathrm{b}}$ & $20.9^{\mathrm{a}}$ & $17.6^{\mathrm{ab}}$ & $20.8^{\mathrm{a}}$ & 0.73 \\
\hline 3 & $23.9^{\mathrm{c}}$ & $28.3^{\mathrm{a}}$ & $23.3^{\mathrm{c}}$ & $26.7^{\mathrm{b}}$ & 0.76 \\
\hline 4 & $29.8^{\mathrm{c}}$ & $35.3^{\mathrm{a}}$ & $32.0^{\mathrm{b}}$ & $31.6^{\mathrm{c}}$ & 0.95 \\
\hline 5 & $36.2^{\mathrm{b}}$ & $42.0^{\mathrm{a}}$ & $38.7^{\mathrm{b}}$ & $36.0^{\mathrm{b}}$ & 0.57 \\
\hline 6 & $42.8^{\mathrm{c}}$ & $49.1^{\mathrm{a}}$ & $45.6^{\mathrm{b}}$ & $40.4^{\mathrm{c}}$ & 0.56 \\
\hline 7 & $48.5^{\mathrm{b}}$ & $54.9^{\mathrm{a}}$ & $52.8^{\mathrm{a}}$ & $43.7^{\mathrm{c}}$ & 0.60 \\
\hline 8 & $54.4^{\mathrm{b}}$ & $60.4^{\mathrm{a}}$ & $60.2^{\mathrm{a}}$ & $47.3^{\mathrm{c}}$ & 0.98 \\
\hline 9 & $62.7^{\mathrm{b}}$ & $64.8^{\mathrm{b}}$ & $67.8^{\mathrm{a}}$ & $50.4^{\mathrm{c}}$ & 0.36 \\
\hline 10 & $68.6^{\mathrm{b}}$ & $68.4^{\mathrm{b}}$ & $72.0^{\mathrm{a}}$ & $56.9^{\mathrm{c}}$ & 0.53 \\
\hline 11 & $70.4^{\mathrm{a}}$ & $71.5^{\mathrm{a}}$ & $71.6^{\mathrm{a}}$ & $56.4^{\mathrm{b}}$ & 0.63 \\
\hline 12 & $70.5^{\mathrm{b}}$ & $75.4^{\mathrm{a}}$ & $72.2^{\mathrm{b}}$ & $57.8^{\mathrm{c}}$ & 0.44 \\
\hline
\end{tabular}

SD, sawdust; WS, wood shavings; S+W, mixture of sawdust and wood shavings ( $1: 1$ in volume); RH, rice hulls; SEM, standard error of means.

a-c Means within in a row without a common superscript letter differ $(\mathrm{p}<0.05)$. 
Table 5. The ammonia emission rate of bedding materials measured by the chamber system

\begin{tabular}{lccccc}
\hline \multirow{2}{*}{ Time (h) } & \multicolumn{4}{c}{ Ammonia emission rate $\left(\mathrm{mg} / \mathrm{m}^{2} / \mathrm{h}\right)$} & \multirow{2}{*}{ SEM } \\
\cline { 2 - 5 } & SD & WS & S $+\mathrm{W}$ & RH & \\
\hline 1 & $3.86^{\mathrm{b}}$ & $6.49^{\mathrm{a}}$ & $2.98^{\mathrm{b}}$ & $5.17^{\mathrm{a}}$ & 0.91 \\
3 & $3.69^{\mathrm{b}}$ & $2.81^{\mathrm{b}}$ & $3.68^{\mathrm{b}}$ & $5.01^{\mathrm{a}}$ & 0.33 \\
6 & $1.58^{\mathrm{b}}$ & $0.47^{\mathrm{c}}$ & $1.87^{\mathrm{b}}$ & $4.10^{\mathrm{a}}$ & 0.21 \\
12 & $0.79^{\mathrm{b}}$ & $0.00^{\mathrm{c}}$ & $1.02^{\mathrm{b}}$ & $3.01^{\mathrm{a}}$ & 0.17 \\
24 & $0.09^{\mathrm{b}}$ & $0.00^{\mathrm{b}}$ & $0.37^{\mathrm{b}}$ & $0.88^{\mathrm{a}}$ & 0.09 \\
36 & 0.19 & 0.00 & 0.47 & 0.70 & 0.09 \\
Mean & $1.70^{\mathrm{b}}$ & $1.63^{\mathrm{b}}$ & $1.73^{\mathrm{b}}$ & $3.15^{\mathrm{a}}$ & 0.31 \\
\hline
\end{tabular}

SD, sawdust; WS, wood shavings; S+W, mixture of sawdust and wood shavings (1:1 in volume); RH, rice hulls; SEM, standard error of means.

${ }^{\mathrm{a}-\mathrm{c}}$ Means within in a row without a common superscript letter differ $(\mathrm{p}<0.05)$.

to $10 \mathrm{~h}$ with intermediate values for $\mathrm{S}+\mathrm{W}$. At the final experimental time $(12 \mathrm{~h})$, the highest moisture evaporation rate was observed in WS $(75.4 \%)$ among treatments $(p<0.05)$, but the differences among wood-based materials were not large with no statistical difference between SD $(70.5 \%)$ and $\mathrm{S}+\mathrm{W}(72.2 \%)$. Limited data are available about the moisture evaporation rates of bedding materials. Ahn et al. (2015) reported a similar result, in which the moisture evaporation rate of SD at $12 \mathrm{~h}$ was $71.2 \%$.

In vitro ammonia emission: In vitro ammonia emission rates by the type of bedding material are shown in Table 5 and total ammonia emissions are shown in Table 6 and Figure 1. According to Misselbrook and Powell (2005), and Ahn et al. (2015), ammonia emissions were variable by the type of bedding materials, and estimating ammonia emissions at farm may be incorrect because of various external factors, such as wind, humidity, and amount of fecal load.
Table 6. Total ammonia emissions from bedding materials measured by the chamber system

\begin{tabular}{|c|c|c|c|c|c|}
\hline \multirow{2}{*}{ Time (h) } & \multicolumn{4}{|c|}{ Ammonia emission $\left(\mathrm{mg} / \mathrm{m}^{2}\right)$} & \multirow{2}{*}{ SEM } \\
\hline & SD & WS & $\mathrm{S}+\mathrm{W}$ & $\mathrm{RH}$ & \\
\hline 1 & $3.86^{\mathrm{b}}$ & $6.49^{\mathrm{a}}$ & $2.98^{\mathrm{b}}$ & $5.17^{\mathrm{a}}$ & 0.71 \\
\hline 3 & $11.24^{\mathrm{b}}$ & $12.11^{\mathrm{b}}$ & $10.34^{\mathrm{b}}$ & $15.19^{\mathrm{a}}$ & 0.67 \\
\hline 6 & $15.98^{\mathrm{b}}$ & $13.52^{\mathrm{b}}$ & $15.95^{\mathrm{b}}$ & $27.49^{\mathrm{a}}$ & 0.94 \\
\hline 12 & $20.72^{b}$ & $13.52^{\mathrm{c}}$ & $22.07^{\mathrm{b}}$ & $45.55^{\mathrm{a}}$ & 0.71 \\
\hline 24 & $21.80^{\mathrm{b}}$ & $13.52^{\mathrm{c}}$ & $26.51^{\mathrm{b}}$ & $56.11^{\mathrm{a}}$ & 0.81 \\
\hline 36 & $24.08^{\mathrm{c}}$ & $13.52^{\mathrm{d}}$ & $32.15^{\mathrm{b}}$ & $64.51^{\mathrm{a}}$ & 0.90 \\
\hline
\end{tabular}

SD, sawdust; WS, wood shavings; S+W, mixture of sawdust and wood shavings ( $1: 1$ in volume); RH, rice hulls; SEM, standard error of means.

${ }^{a-d}$ Means within in a row without a common superscript letter differ $(\mathrm{p}<0.05)$.

At $1 \mathrm{~h}$, ammonia emissions of WS $\left(6.49 \mathrm{mg} / \mathrm{m}^{2} / \mathrm{h}\right)$ were approximately 2 times higher $(\mathrm{p}<0.05)$ than SD $(3.86$ $\left.\mathrm{mg} / \mathrm{m}^{2} / \mathrm{h}\right)$ and $\mathrm{S}+\mathrm{W}\left(2.98 \mathrm{mg} / \mathrm{m}^{2} / \mathrm{h}\right)$. After $3 \mathrm{~h}$, differences were not observed among SD, WS, and $\mathrm{S}+\mathrm{W}$, except for WS at 6 and $12 \mathrm{~h}$. The RH showed the highest ammonia emissions until $24 \mathrm{~h}$ and the average ammonia emission rate during the whole experimental time was higher $(\mathrm{p}<0.05)$ than SD, WS, and S+W.

Total ammonia emissions $\left(\mathrm{mg} / \mathrm{m}^{2}\right)$ of bedding materials clearly revealed the differences in ammonia absorption capacity among bedding materials. The RH treatment showed higher total ammonia emissions than other treatments during the whole experimental time $(p<0.05)$. After $12 \mathrm{~h}$ of experiment, WS showed the lowest $(\mathrm{p}<0.05)$ total ammonia emissions among treatments, maintaining comparatively low value $\left(13.52 \mathrm{mg} / \mathrm{m}^{2}\right)$ from 6 to $36 \mathrm{~h}$. No differences were observed between SD and $\mathrm{S}+\mathrm{W}$, except at $36 \mathrm{~h}$.

Higher total ammonia emissions of WS and RH than SD

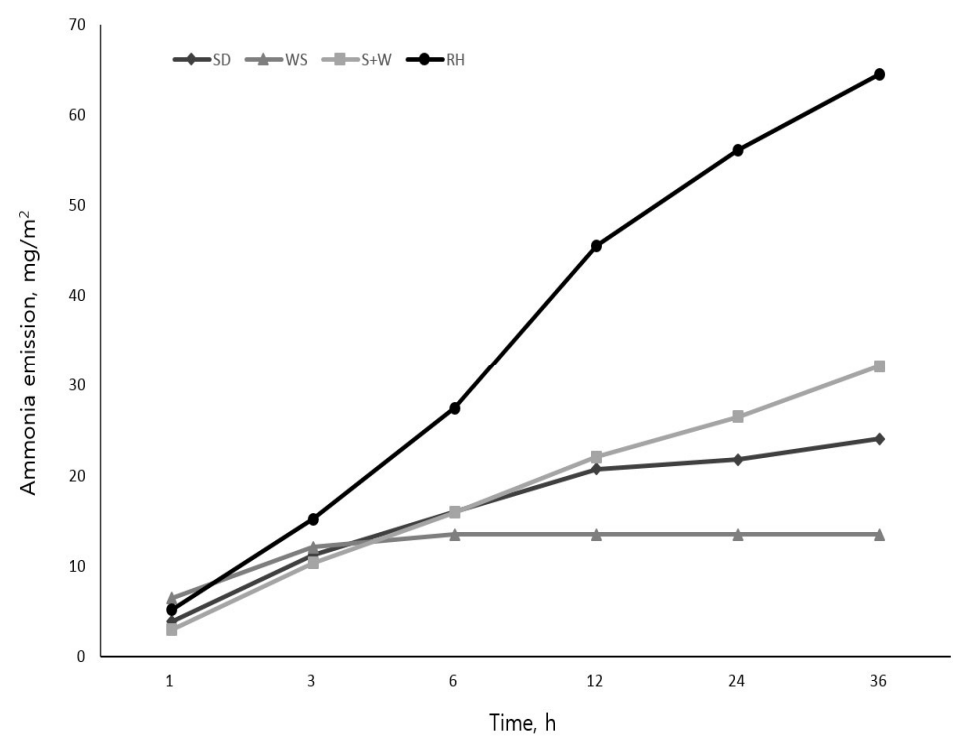

Figure 1. Total ammonia emissions of bedding materials measured by the chamber system. SD, sawdust; WS, wood shavings; S+W, mixture of sawdust and wood shavings (1:1 in volume); $\mathrm{RH}$, rice hulls. 
and $\mathrm{S}+\mathrm{W}$ at $1 \mathrm{~h}$ seemed to be a result from the high porosity of WS and RH, caused by relatively higher particle size than SD and S+W. However, WS showed a lower amount of total ammonia emission than other treatments as time progressed, probably due to high water absorption capacity. Likewise, the RH treatment emitted more than twice the total amount of ammonia $\left(64.51 \mathrm{mg} / \mathrm{m}^{2}\right)$ than other treatments, probably caused by low water absorption capacity. In summary of the results from the physicochemical properties, using $\mathrm{S}+\mathrm{W}$ is recommended as a bedding material when considering lower proportion of fine particles $(250 \mu \mathrm{m}+<250 \mu \mathrm{m})$ than SD and higher bulk density than WS with relatively good moisture evaporation rate.

\section{Exp. II. The evaluations of by types of bedding materials for Hanwoo cattle}

Moisture concentration: The moisture concentrations by the types of bedding materials are shown in Table 7. No significant interactions between bedding type and location within a pen were observed throughout the whole experimental period. At the first week of experiment, SD $(53.3 \%)$ and S+W (54.6\%) showed lower moisture concentrations than WS $(59.5 \% ; \mathrm{p}<0.05)$ at side A. At week 2 and $3, \mathrm{SD}, \mathrm{WS}$, and $\mathrm{S}+\mathrm{W}$ did not show statistical differences ( $p>0.05$ ), and ranged from $61.0 \%$ to $72.5 \%$ at side A. At the third week of experimental weeks, moisture concentrations were over $65 \%$ in all treatments, thus beddings were replaced with fresh new bedding materials. According to Kweon et al. (1995), beddings must be replaced when moisture concentrations over $65 \%$. In side A, the average moisture concentration of WS (65.7\%) was higher $(\mathrm{p}<0.05)$ than those of SD $(62.5 \%)$ and $\mathrm{S}+\mathrm{W}$ $(61.6 \%)$.

Table 7. Effects of bedding materials and pen location on moisture concentrations of beddings for rearing Hanwoo

\begin{tabular}{lccccc}
\hline \multirow{2}{*}{ Side } & \multirow{2}{*}{ Week } & \multicolumn{3}{c}{ Moisture concentration (\%) } & \multirow{2}{*}{ SEM } \\
\cline { 2 - 5 } & & SD & WS & S+W & \\
\hline A & 1 & $53.3^{\mathrm{b}}$ & $59.5^{\mathrm{a}}$ & $54.6^{\mathrm{b}}$ & 1.21 \\
& 2 & $64.2^{\mathrm{n}}$ & 65.2 & 61.0 & 1.12 \\
& 3 & 70.0 & 72.5 & 69.2 & 1.47 \\
& Mean & $62.5^{\mathrm{bA}}$ & $65.7^{\mathrm{aA}}$ & $61.6^{\mathrm{bA}}$ & 1.31 \\
$\mathrm{~B}$ & 1 & $35.9^{\mathrm{b}}$ & $47.8^{\mathrm{a}}$ & $43.5^{\mathrm{a}}$ & 1.02 \\
& 2 & $57.1^{\mathrm{a}}$ & $57.4^{\mathrm{a}}$ & $45.5^{\mathrm{b}}$ & 1.42 \\
& 3 & $63.5^{\mathrm{b}}$ & $68.4^{\mathrm{a}}$ & $62.9^{\mathrm{b}}$ & 1.38 \\
& Mean & $52.2^{\mathrm{bB}}$ & $57.9^{\mathrm{aB}}$ & $50.7^{\mathrm{bB}}$ & 1.27 \\
\hline
\end{tabular}

SD, sawdust; WS, wood shavings; S+W, mixture of sawdust and wood shavings (1:1 in volume); SEM, standard error of means.

Side A, feed bunk side within a pen; Side B, water supply side within a pen.

Means within in a row without a common superscript letter differ $(\mathrm{p}<0.05)$.

Means within in a column without a common superscript capital letter differ $(\mathrm{p}<0.01)$.
At week 1 in side B, SD (35.9\%) showed lower moisture concentration $(\mathrm{p}<0.05)$ than WS $(47.8 \%)$ and $\mathrm{S}+\mathrm{W}$ $(43.5 \%)$. However, the WS treatment showed the highest moisture concentrations among treatments at week 3 $(\mathrm{p}<0.05)$. The average moisture concentration of WS $(57.9 \%)$ was also higher $(\mathrm{p}<0.05)$ than those of SD $(52.2 \%)$ and $\mathrm{S}+\mathrm{W}(50.7 \%)$. Regardless of type of bedding materials, moisture concentrations of beddings within a pen were lower $(\mathrm{p}<0.01)$ at side B than A, meaning that side B can be used longer than side $\mathrm{A}$.

Ahn et al. (2015) reported using cocopeat beddings can extend the bedding utilization period to twice that of SD. However, the utilization period among bedding materials was not different in this study. Overall, using WS alone as a bedding material showed higher moisture concentrations than $\mathrm{SD}$ and $\mathrm{S}+\mathrm{W}$, and $\mathrm{SD}$ and $\mathrm{S}+\mathrm{W}$ did not show significant differences.

Moisture increment: The moisture increment by the types of bedding materials is presented in Table 8. Moisture increments (\% unit) were calculated by subtracting the moisture concentrations from each experimental week from values of the week before. In side $A$ at 1 week, moisture increment of WS $(27.5)$ was higher $(p<0.05)$ than those of $\mathrm{SD}$ (14.3) and $\mathrm{S}+\mathrm{W}$ (19.0). In addition, the average moisture increment of WS $(13.5 \%$ unit $)$ was higher $(\mathrm{p}<0.05)$ than those of SD (10.3) and $\mathrm{S}+\mathrm{W}$ (11.2). From week 2 to 3 , the effect of bedding materials was, however, variable and no clear tendency was observed.

In side $\mathrm{B}$ at week 1 , moisture increment of beddings were higher in WS than others. The SD treatment showed negative moisture increment $(-3.1)$ at the first week. However, a dramatic increase (21.2) was observed at week 2. The $\mathrm{S}+\mathrm{W}$ treatment showed the lowest moisture increment (2.1) in side B at week 2, but showed the highest

Table 8. Effects of bedding materials and pen location on moisture increment of beddings for rearing Hanwoo

\begin{tabular}{lccccc}
\hline \multirow{2}{*}{ Side } & \multirow{2}{*}{ Week } & \multicolumn{3}{c}{ Moisture increment (\% unit) } & \multirow{2}{*}{ SEM } \\
\cline { 2 - 5 } & & SD & WS & S $+W$ & \\
\hline A & 1 & $14.3^{\mathrm{c}}$ & $27.5^{\mathrm{a}}$ & $19.0^{\mathrm{b}}$ & 1.18 \\
& 2 & $10.8^{\mathrm{a}}$ & $5.8^{\mathrm{b}}$ & $6.4^{\mathrm{b}}$ & 1.28 \\
& 3 & $5.9^{\mathrm{b}}$ & $7.3^{\mathrm{ab}}$ & $8.1^{\mathrm{a}}$ & 1.23 \\
& Mean & $10.3^{\mathrm{bA}}$ & $13.5^{\mathrm{aA}}$ & $11.2^{\mathrm{bA}}$ & 1.23 \\
$\mathrm{~B}$ & 1 & $-3.1^{\mathrm{c}}$ & $15.8^{\mathrm{a}}$ & $7.9^{\mathrm{b}}$ & 1.41 \\
& 2 & $21.2^{\mathrm{a}}$ & $9.6^{\mathrm{b}}$ & $2.1^{\mathrm{c}}$ & 1.75 \\
& 3 & $6.4^{\mathrm{c}}$ & $11.1^{\mathrm{b}}$ & $17.4^{\mathrm{a}}$ & 2.47 \\
& & $8.2^{\mathrm{bB}}$ & $12.2^{\mathrm{aB}}$ & $9.1^{\mathrm{bB}}$ & 1.88 \\
\hline
\end{tabular}

SD, sawdust; WS, wood shavings; S+W, mixture of sawdust and wood shavings ( $1: 1$ in volume); SEM, standard error of means.

Side A, feed bunk side within a pen; Side B, water supply side within a pen.

Means within in a row without a common superscript letter differ $(\mathrm{p}<0.05)$.

Means within in a column without a common superscript capital letter differ $(\mathrm{p}<0.01)$. 
moisture increment (17.4) at week 3. Similar to the result from Side A, the average moisture increment in side B were higher in WS (12.2) than SD (8.2) and S+W (9.1). Regardless of type of bedding materials, the average moisture increments of beddings within a pen were higher $(\mathrm{p}<0.01)$ at side $\mathrm{A}$ than $\mathrm{B}$.

As a result of the evaluations of bedding materials by types, SD and $\mathrm{S}+\mathrm{W}$ is more efficient than WS as bedding materials for rearing Hanwoo cattle. The amount of bedding materials used within a pen (5 cm thickness) was 291.9, 75.4 , and $183.7 \mathrm{~kg}$ for SD, WS, and $\mathrm{S}+\mathrm{W}$, respectively. The differences were caused by the low bulk density of WS. Thus, considering the physicochemical property, moisture increment and economic aspects, using $\mathrm{S}+\mathrm{W}$ for beddings would be a better choice than SD or WS alone. Any negative effect on animal health was not observed during the whole experimental period.

\section{CONCLUSION}

Based on the results from physicochemical test and onfarm trial, using the mixture of SD and WS (1:1 in volume) can be a good choice for better utilization of bedding materials. Rice hulls are not suitable for bedding materials because of low rate of water absorption and moisture evaporation. In addition, bedding materials can used more effectively on the water supply side compared to feed bunk side with in a pen.

\section{CONFLICT OF INTEREST}

We certify that there is no conflict of interest with any financial organization regarding the material discussed in the manuscript.

\section{ACKNOWLEDGMENTS}

This study was supported by 'Cooperative Research Program for Agriculture Science and Technology Development (Project No. PJ011995)' Rural Development Administration, Republic of Korea.

\section{REFERENCES}

Ahn, G. C., K. Y. Lee, H. J. Kwak, W. S. Kwak, Y. K. Oh, S. S. Jang, and K. K. Park. 2015. Characteristics of sawdust and cocopeat beddings, and its usefulness according to the fan and pen location for rearing Hanwoo cattle. Asian Australas. J. Anim. Sci. 29:444-454.

Burkholder, K. M., A. D. Guyton, J. M. McKinney, and K. F. Knowlton. 2004. The effect of steam flaked or dry ground corn and supplemental phytic acid on nitrogen partitioning in lactating cows and ammonia emission from manure. J. Dairy Sci. 87:2546-2553.

Kweon, D. J., U. G. Kweon, S. G. Jeong, J. D. Han, S. C. Jung, S. W. Kang, S. L. Kang, H. S. Jung, and H. J. Chang. 1995. Study on the utilization of sawdust bedding barn for dairy cows. II. Comparision of utilization efficiency of the different depth of sawdust bedding for dairy cows. Kor. Soc. Livest. Hous. Environ. 1:117-124.

Lowe, D. E., R. W. J. Steen, V. E. Beattie, and B. W. Moss. 2001. The effects of floor type systems on the performance, cleanliness, carcass composition and meat quality of housed finishing beef cattle. Livest. Prod. Sci. 69:33-42.

Misselbrook, T. H. and J. M. Powell. 2005. Influence of bedding material on ammonia emissions from cattle excreta. J. Dairy Sci. 88:4304-4312.

Olson, T. M. 1940. Absorptive capacity of different materials ordinarily used for bedding. J. Dairy. Sci. 23:355-360.

SAS. 2002. SAS User's Guide, Statistics, Version 9.03 Edition. SAS Inst., Inc., Cary, NC, USA.

RSPCA (Royal Society for the Prevention of Cruelty to Animals). 2015. The five freedoms. https://www.rspca.org.uk/servlet/ Satellite?blobcol=urlblob\&blobheader $=$ application $\% 2$ Fpdf\&bl obkey $=$ id\&blobtable $=$ RSPCABlob\&blobwhere $=12106831961$ 22\&ssbinary=true. Accessed September 30, 2015. 